\title{
Defective platelet aggregation to the calcium ionophore A23187 in a patient with a lifelong bleeding disorder
}

\author{
SJ MACHIN, JP KEENAN, ${ }^{*}$ BA McVERRY* \\ From the Department of Haematology, The Middlesex Hospital Medical School, London W1 and the \\ ${ }^{*}$ Department of Haematology, Liverpool University
}

SUMMARY A patient with a lifelong bleeding disorder is presented with a prolonged bleeding time and abnormal aggregation and secretion responses to arachidonic acid, thromboxane $A_{2}, P A F-$ acether and the divalent calcium ionophore A23187. Platelet $\alpha$ and dense granule contents and morphology appear normal. The proposed defect is due to an abnormality of a platelet intracellular calcium dependent process.

When platelets are activated, arachidonate is enzymatically released from platelet membrane phospholipids and subsequently converted via cyclo-oxygenase and thromboxane synthetase into the cylic endoperoxides, $\mathrm{PGG}_{2}$ and $\mathrm{PGH}_{2}$ and to thromboxane $\mathrm{A}_{2}\left(\mathrm{TXA}_{2}\right) .{ }^{1}$ These compounds and especially $\mathrm{TXA}_{2}$ are potent inducers of platelet aggregation and granule secretion. It has been suggested that TXA $_{2}$ may act as a calcium ionophore, releasing stored calcium from the dense tubular system and thus raising the level of free cytoplasmic calcium. $^{2}$

Mobilisation of intracellular calcium is involved in the regulation of several platelet functions and secretory processes, suggesting a controlling trigger role for intracellular calcium flux and free cytoplasmic calcium in the platelet activation process. ${ }^{3}$

Recently, a few patients have been described with a lifelong bleeding tendency in whom arachidonate metabolism including TXA formation was normal but whose platelets were unresponsive to TXA $_{2}$ showing defective aggregation and granule release.$^{4-8}$ Also a similar acquired defect has been reported in one patient with chronic myeloid leukaemia. ${ }^{9}$

We present here a patient with a lifelong bleeding tendency who has abnormal aggregation and secretion responses suggestng a defect in either the mobilisation of intracellular calcium, or a response to free cytoplasmic calcium.

Accepted for publication 1 June 1983

\section{Patient and methods}

CASE REPORT

A 57-year-old Caucasian housewife presented with a lifelong bleeding disorder. As a child, she had fre quent epistaxis lasting up to $24 \mathrm{~h}$ at a time until 16 years old. Since then, she has had widespread spon? taneous non-traumatic purpura but not excessive menstrual loss or serious bleeding episodes. She had no operations in the past and had previously been told to avoid all drugs. She did not imbibe alcohol. A family history was relevant in that two brothers died in childhood from uncontrollable haemorrhage after minor trauma in one case and abdominal surgery in the other. Two other sisters and a brother were untroubled by bleeding, one sister having had an uncomplicated appendicectomy. Her parents had lived into old age without any bleeding problems. Physical examination was normal apart from some purpuric lesions on the lower limbs. Initial studies showed a normal blood and platelet count, normal renal and liver biochemical profiles and normal concentrations of immunoglobulin.

\section{Methods}

As anticoagulant, one volume of $3.13 \%$ sodium citrate was used for nine volumes of blood. Platelet-rich plasma (PRP) and platelet-poor plasma (PPP) were prepared by centrifugation at $164 \mathrm{~g}$ for $10 \mathrm{~min}$ and $1465 \mathrm{~g}$ for $15 \mathrm{~min}$ respectively at $22^{\circ} \mathrm{C}$. Bleeding times were performed by the template method using a Simplate-II from General 
Diagnostics. Platelet counts were performed using a Technicon Autocounter (Technicon Instruments). Coagulation parameters were performed by standard techniques. ${ }^{10}$

The patient had been examined on four occasions. On each occasion a healthy control subject, who had ingested no drugs for the previous 14 days, and a control subject who had ingested $900 \mathrm{mg}$ of acetylsalicylic acid $12 \mathrm{~h}$ previously, were studied simultaneously.

Platelet-aggregation studies were performed with an Aggregraph dual-channel aggregometer at $37^{\circ} \mathrm{C}$. Aliquots of PRP $(500 \mu \mathrm{l})$ or washed platelet suspensions, with a final platelet count of 200-300 $\times 10 \% / 1$ were placed in a cuvette in the aggregometer and aggregation induced with a final concentration of $2-16 \mu \mathrm{mol} / 1$ adenosine-5'-diphosphate (ADP Sigma), $1-2 \mu \mathrm{mol} / 1$ arachidonic acid, sodium salt (Sigma), $1.0-1.5 \mathrm{mg} / \mathrm{ml}$ ristocetin (H Lundbeck, Copenhagen), 1-6 $\mu \mathrm{g} / \mathrm{ml}$ collagen (Hormon Chemie, Munchen), $0.5-2.5 \mathrm{mg} / \mathrm{ml}$ endoperoxide analogue U-44069 (kindly supplied by Dr GL Bundy, Upjohn, Kalamazoo, Michigan), 1-12.5 $\mu \mathrm{mol} / \mathrm{l}$ ionophore A23187 (Calbiochem, La Jolla, California), $\quad 0.5-2.5 \mathrm{mg} / \mathrm{ml}$. PAF-acether ( 1-0-alkyl -2-acetyl-glyceryl-3-phosphorylcholine; Calbiochem, La Jolla, California) and 0.2-1.0 U/ml human thrombin (Blood Products Laboratory, Elstree, UK). Platelets were washed by an albumin gradient separation technique ${ }^{11}$ and resuspended in a calcium-free TRIS $\mathrm{HCl}$ buffered saline, $\mathrm{pH} 7 \cdot 4$.

Platelet electron microscopy, thromboxane $\mathbf{B}_{2}$ $\left(\mathrm{TXB}_{2}\right)$ in serum and after release from platelets in response to various stimuli, malondialdehyde (MDA) formation after stimulation with $1 \mathrm{mmol} / \mathrm{l}$ $\mathrm{N}$-ethylmaleimide (NEM), plasma 6-keto prostaglandin F1 $\alpha$ and cyclic AMP levels in unstimulated PRP were assayed as previously described..$^{12}$ Platelet lysate was examined for antigenic material related to platelet PF4 and factor VIII:Rag. ${ }^{13}$

The concentrations of the platelet nucleotides ATP and ADP and their release after platelet stimulation by various agonists were determined by the firefly-luminescence method as described previously. ${ }^{14}$ The PRP was corrected to a final platelet count of $300 \times 10^{9} / 1$ in all experiments involving platelet nucleotide determinations.

\section{Results}

The patient consistently had a prolonged bleeding time of $>30$ minutes with a platelet count ranging between 223-357 $\times 10^{9} / 1$. All the coagulation parameters including the thrombin time, prothrombin time, activated partial thromboplastin time, factor VIII:C, factor VIII:Rag and factor VIII:RiCoF gave normal results.

Aggregation tracings of the patients and normal control PRP in response to ADP, collagen, arachidonic acid, U44069, A23187 and PAFacether are shown in Fig. 1. Aggregation was reversible with ADP (2-16 $\mu \mathrm{mol} / \mathrm{l})$, with the endoperoxide analogue U44069 $(0.5-2.5 \mu \mathrm{g} / \mathrm{ml})$ and with PAF-acether (0.05-0.5 $\mu \mathrm{g} / \mathrm{ml})$. Aggregation was delayed and reduced in response to arachidonic acid $(0 \cdot 5-2 \mathrm{mmol} / \mathrm{l})$ collagen $(1-6 \mu \mathrm{g} / \mathrm{ml})$ and the calcium ionophore A23187 (1-12.5 $\mu \mathrm{mol} / \mathrm{l})$. Ristocetin $(1 \cdot 0-1 \cdot 5 \mathrm{mg} / \mathrm{ml})$ gave normal aggregation. Upon stimulation the patient's platelets underwent a normal shape change to all the above agonists. Aggregation of washed platelets with thrombin $(0 \cdot 2-1 \cdot 0$ $\mathrm{U} / \mathrm{ml}$ ) was normal. Normal washed platelets do not form platelet aggregates in response to A23187 (1-2 $\mu \mathrm{mol} / \mathrm{l}),{ }^{15}$ but on the addition of $0.5 \mathrm{mmol} / \mathrm{l}$ exogenous calcium both control and the patient's washed platelets produced similar aggregation responses.

In a transfer experiment, PRP from the patient and control were stirred in the aggregometer for $30 \mathrm{~s}$ after the addition of $1 \mathrm{mmol} / \mathrm{l}$ arachidonic acid. After rapid centrifugation for $30 \mathrm{~s}, 100 \mu \mathrm{l}$ of each platelet poor supernatant was added to $400 \mu \mathrm{l}$ of PRP from the patient or from a normal subject who had ingested $900 \mathrm{mg}$ of aspirin 12 hours previously. These mixtures were stirred in the aggregometer and aggregation recorded (Fig. 2). Supernatant from the control induced full aggregation of the aspirintreated PRP but none with the patient's PRP. Similarly supernatant from the patient induced full aggregation of the aspirin-treated PRP but none with the patient's own PRP.

Malondialdehyde formation, serum thromboxane $\mathrm{B}_{2}\left(\mathrm{TXB}_{2}\right)$ production and the generation of thromboxane $\mathrm{B}_{2}$ from PRP after stimulation with $2 \mu \mathrm{g} / \mathrm{ml}$ collagen and $1 \mathrm{mmol} / \mathrm{l}$ arachidonic acid, and plasma 6-keto prostaglandin $F_{1} \alpha$ levels are shown from the patient and a normal subject who had ingested $900 \mathrm{mg}$ of aspirin 12 hours previously in Table 1.

The patient's total platelet ATP and ADP contents and ATP/ADP ratio were within our normal range as previously reported..$^{14}$ The percentage release of platelet ATP and ADP after stimulation with A23187, collagen and PAF-acether are also shown for the patient and a normal control (Table 2).

The total ATP and ADP contents and ATP/ADP ratio from washed platelets of the patient and a normal subject and the percentage release of platelet ATP and ADP after stimulation with A23187 are shown in Table 3.

By light and electron microscopy the patient's platelets showed normal morphology and granule 


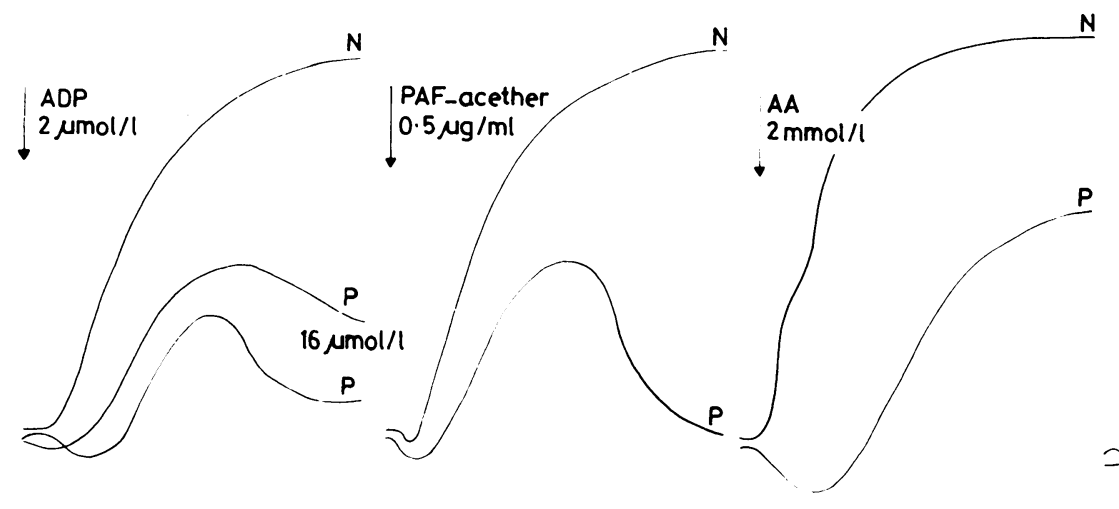

$\mathrm{N}$
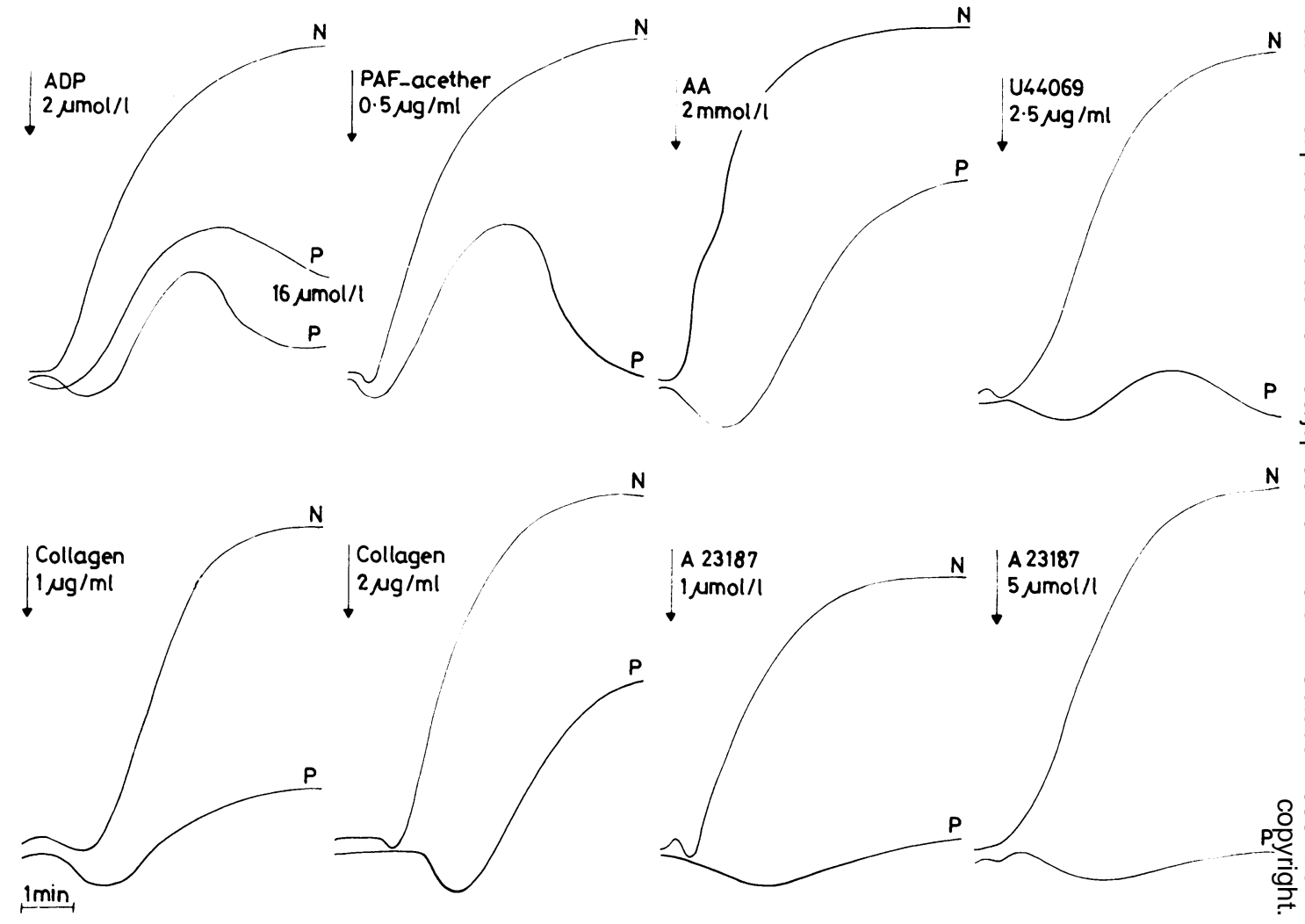

Fig 1 Aggregation tracings of the patient $(P)$ and normal control $(N)$ to various agonists.

content. Intra platelet PF4 and factor VIII:Rag content appear to be normal. The concentration of cyclic AMP in the patient's unstimulated PRP was $23.71 \mathrm{pmol} / 10^{8}$ platelets (normal range $14 \cdot 7-33 \cdot 8$ $\mathrm{pmol} / 10^{8}$ platelets).

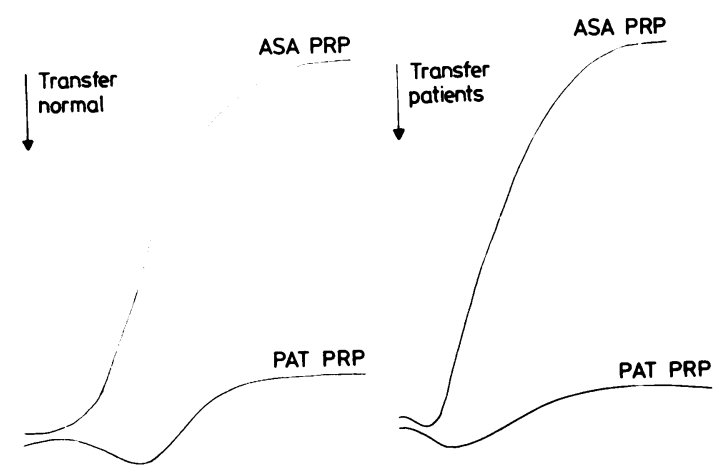

Fig. 2 Aggregation tracings after transfer of an aliquot of normal and patient platelet poor supernatant to aspirin treated platelets (ASA PRP) and patient platelets (PAT $P R P)$.
1 able 1 Parameters of arachidonic acid metabolism in the $\overline{\vec{B}}$ patient and control subject who had ingested acetylsalicylic acid (ASA:control)

\begin{tabular}{|c|c|c|c|}
\hline & Patient & ASA:Control & Normal range \\
\hline \multirow{5}{*}{ 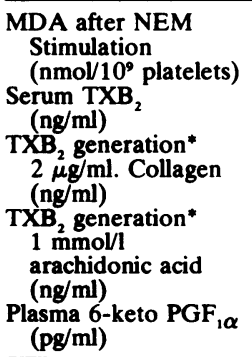 } & $3 \cdot 2$ & $<0.2$ & $1 \cdot 1-3 \cdot 94$ \\
\hline & 409 & $<10$ & $200-900$ \\
\hline & 272 & $<10$ & $163-297$ \\
\hline & 303 & $<10$ & $251-394$ \\
\hline & 24 & $<10$ & $0-80$ \\
\hline \multicolumn{4}{|c|}{$\begin{array}{l}\text { *The platelet counts of PRP were all corrected to } 300 \times 10^{\circ} / 1 \text { and } \\
\text { the stimulus applied for } 4 \text { min in the aggregometer. }\end{array}$} \\
\hline Conclusions & & & \\
\hline
\end{tabular}

This patient's platelets were normal in number and 0 morphology and contained normal $\alpha$ and dense $\bar{\partial}$ granule contents. However, they showed markedly 
Table 2 Percentage release of platelet nucleotides after stimulation of PRP for 4 min in the aggregometer with the agonists. Each value is the mean of two determinations.

\begin{tabular}{llrlll}
\hline $\begin{array}{l}\text { Agonists } \\
\text { (final concentration) }\end{array}$ & \multicolumn{2}{l}{ Patient } & & \multicolumn{2}{c}{ Control subject } \\
\cline { 2 - 3 } \cline { 6 - 7 } & $A T P$ & $A D P$ & & $A T P$ & $A D P$ \\
\hline $2.5 \mu \mathrm{mol} / \mathrm{l}$ A32187 & 3.2 & 5.9 & & 14.7 & 6.0 \\
$6.25 \mu \mathrm{mol} / \mathrm{l}$ A23187 & 4.7 & 17.7 & & 19.7 & 57.6 \\
$2 \mu \mathrm{g} / \mathrm{ml}$ collagen & 3.7 & 9.9 & & 35.6 & 77.6 \\
$6 \mu \mathrm{ml}$ collagen & 6.4 & 15.4 & & 34.1 & 94.5 \\
$0.05 \mu \mathrm{g} / \mathrm{ml}$ PAF-acether & 1.7 & 1.8 & & 10.9 & 24.9 \\
$0.5 \mu \mathrm{m} / \mathrm{ml}$ PAF-acether & 1.8 & 3.2 & & 16.5 & 49.1 \\
\hline
\end{tabular}

abnormal aggregation responses to ADP, arachidonate, low and high dose collagen, endoperoxide analogue, PAF-acether and A23187. This is suggestive of a defect in the prostaglandin pathway. We were able to exclude production of a biologically abnormal TXA molecule, as has previously been described $^{16}$ by showing that $\mathrm{TXA}_{2}$-like material from our patient's platelets produced normal aggregation of aspirin-treated normal platelets. In addition, platelet $\mathrm{TXB}_{2}$ and malondialdehyde production were quantitatively normal. We also excluded the possibility that our patient's platelets did not respond to endogenous $\mathrm{TXA}_{2}$-like material due to a $\mathrm{TXA}_{2} / \mathrm{PGH}_{2}$ receptor abnormality as has been reported. ${ }^{5}$ That patient had normal aggregation and release to A23187. Similarly, A23187 induced aggregation is not inhibited by the TXA receptor blocking compound AH 19437. ${ }^{17}$ It has been reported that high dose collagen and PAFacethe ${ }^{18}$ induce platelet aggregation and release independently of arachidonate metabolism and $\mathrm{TXA}_{2}$ generation. Our patient's platelets showed defective aggregation and release in response to collagen, PAF-acether and A23187. Furthermore, it is now accepted that A23187 induced aggregation is dependent on the mobilisation and response to intracellular platelet calcium. This would suggest a defect in either calcium content, mobilisation or utilisation of intracellular calcium. This concept is supported by the fact that platelet aggregation induced by A23187 was corrected by the addition of exogenous calcium to the washed platelets. This abnormality was not associated with any increase in the basal level of cyclic AMP which is believed to inhibit calcium mobilisation. ${ }^{19}$

Therefore, we propose that our patient has a defect in a calcium dependent process, such as a calcium dependent protease ${ }^{20}$ or a calcium calmodulin binding defect ${ }^{21}$ which is overcome in washed platelets by the presence of extracellular calcium.

\section{References}

'Smith JB. In: Bloom AL, Thomas DP. Haemostasis and thrombosis Edinburgh: Churchill Livingstone, 1981:61-72.

${ }^{2}$ Gerrard JM, Townsend DeW, Stoddard S, Witkop CJ, White JG. The influence of prostaglandin $G_{2}$ on platelet ultrastructure and platelet secretion. Am J Pathol 1977;86:99-107.

${ }^{3}$ Detwiler TC, Charo IF, Feniman RD. Evidence that calcium regulates platelet function. Throm Haemost 1978;40:207-11.

4 Lages B, Malsten C, Weiss HJ, Samuelsson B. Impaired platelet response to thromboxane $A_{2}$ and defective calcium mobilisation in a patient with a bleeding disorder. Blood 1981;57:545-52.

5 Wu KK, Le Breton GC, Tai HH, Chen YC. Abnormal platelet response to thromboxane $A_{2} . J$ Clin Invest 1981;67:1801-4.

- Samama M, Lecrubier C, Conrad J, et al. Constitutional thrombocytopathy with subnormal response to thromboxane $\mathrm{A}_{2} . \mathrm{Br}$ J Haematol 1981;48:293-303.

' Hattori A, Takahashi H, Takahashi M, Shibata A, Okuma M. A new familial defect of platelet release mechanism (the intracellular $\mathrm{Ca}^{++}$transport defect?) Acta Haematologica Japonica 1981;44:969-72.

${ }^{8}$ Hardisty RM, Machin SJ, Nokes TJC, Rink TJ, Smith SW. A new type of congenital defect of platelet secretion:-impaired sensitivity of the platelets to free cytoplasmic calcium ion. $B r J$ Haemtol 1983;53:543-57.

' Ukuma M, Takayama H, Lichino H. Subnormal platelet response to thromboxane $A_{2}$ in a patient with chronic myeloid leukaemia. Br J Haematol 1982;51:469-77.

${ }^{10}$ Biggs R. Human blood coagulation, haemostasis and thrombosis. Oxford: Blackwell Scientific Publications, 1976.

"Walsh PN, Biggs R, Gagnatelli G. Platelet antiheparin activity. Assay based on factor $\mathrm{Xa}$, inactivation by heparin and antifactor Xa. Br J Haematol 1974;26:405-19.

${ }^{12}$ Defreyn G, Machin SJ, Carreras LO, Vergara Dauden M, Chamone DAF, Vermylen J. Familial bleeding tendency with partial platelet thromboxane synthetase deficiency. Reorientation of cyclic endoperoxide metabolism. Br J Haematol $1981 ; 49: 29-42$.

${ }^{13}$ Sultan Y, Jeanneau C, Maisonneuve P, Caen JP. Platelet factor VIII-related antigen. Studies in vivo after transfusion in patients with von Willebrand's disease. Blood 1978;51:75161.

${ }^{14}$ Summerfield GP, Keenan JP, Brodie NJ, Bellingham AJ.

Table 3 Platelet nucleotides levels of washed platelet suspension and the percentage nucleotide release following stimulation with $A 23187$ in a calcium-free medium

\begin{tabular}{|c|c|c|c|c|c|c|}
\hline & \multicolumn{3}{|l|}{ Patient } & \multicolumn{3}{|c|}{ Control subject } \\
\hline & $A T P$ & $A D P$ & Ratio & $A T P$ & $A D P$ & Ratio \\
\hline $\begin{array}{l}\text { Total nucleotide levels } \\
\text { (nmol/10 } 10^{\circ} \text { platelets) }\end{array}$ & $33 \cdot 9$ & $20 \cdot 7$ & $1 \cdot 6: 1$ & $37 \cdot 4$ & $23 \cdot 0$ & $1 \cdot 62: 1$ \\
\hline $\begin{array}{l}0.25 \mu \mathrm{mol} / \mathrm{l} \mathrm{A23187} \\
2.0 \mu \mathrm{mol} / 1 \mathrm{~A} 23187\end{array}$ & $\begin{array}{l}7.7 \% \\
5 \cdot 3 \%\end{array}$ & $\begin{array}{l}28 \cdot 0 \% \\
36 \cdot 7 \%\end{array}$ & & $\begin{array}{l}20 \cdot 1 \% \\
31.7 \%\end{array}$ & $\begin{array}{l}43.3 \% \\
73.3 \%\end{array}$ & \\
\hline
\end{tabular}


Bioluminescent assay of adenine nucleotides: rapid analysis of ATP and ADP in red cells and platelets using the LKB luminometer. Clin Lab Haematol 1981;3:257-71.

${ }^{15}$ Feinstein MB, Fraser C. Human platelet secretion and aggregation induced by calcium ionophores. J Gen Physiol 1975;66:561-81.

${ }^{16}$ Russell NH, Keenan JP, Bellingham AJ. Thrombocytopathy in preleukaemia: association with a defect of thromboxane $A_{2}$ activity. Br J Haematol 1979;41:417-25.

17 Geisow HP, Hornby EJ, McCabe PJ. Inhibition of platelet aggregation by $\mathrm{AH} 19437$, a thromboxane receptor blocking drug. Br J Pharmacol 1981;73:219-20.

1s Chignard M, Le Couedic JP, Vargaftig BB, Benveniste J. Platelet-activating factor (PAF-acether) secretion from platelets: effect of aggregating agents. $\mathrm{Br} J$ Haematol 1980;46:455-64.

19 Haslam RJ, Davidson ML, Fox JB, Lynham JA. Cyclic nucleotides in platelet function. Thromb Haemost 1978;40:232-9.

${ }^{20}$ White GC. Calcium-dependant proteins in platelets. Biochem Biophys Acta 1980;631:130-9.

${ }^{21}$ White GC, Raynor ST. The effects of trifluoperazine, an inhibitor of calmodulin, on platelet function. Thromb Res 1980;18:279-84.

Requests for reprints to: Dr SJ Machin, The Middlesex के Hospital Medical School, Riding House Street, London $\overrightarrow{0}$ W1P 7LD, England.

\section{The September 1983 issue}

\section{THE SEPTEMBER 1983 ISSUE CONTAINS THE FOLLOWING PAPERS}

\section{Symposium report}

Blood culture-current state and future prospects JC GOULD, BI DUERDEN

Isolation of Legionella pneumophila from clinical specimens via amoebae, and the interaction of those and other isolates with amoebae TJ ROWBOTHAM

Bacteriological examination of removed cerebrospinal fluid shunts R BAYSTON, TERESA SM LEUNG, BARBARA M WILKINS, BRENDA HODGES

Evaluation of some methods for the laboratory identification of Haemophilus infuenzae $\mathrm{GM}$ TEBBUTT

Comparison of the continuous cell line 293 with human embryo kidney cells and human embryo fibroblast cells for the cultivation of ocular viruses DL YIRRELL, APCH ROOME, JM DARVILLE, CR ASHLEY, J HARBOUR

Correlation of lysosomal enzyme abnormalities in various forms of adult leukaemia GTN BESLEY, SE MOSS, AD BAIN, AE DEWAR

Hyaline-vascular variant of angiofollicular lymph node hyperplasia with systemic manifestations and response to corticosteroids GP SUMMERFIELD, W TAYLOR, AJ BELLINGHAM, HJ GOLDSMITH

Iron deficiency in sickle cell anaemia SALLY DAVIES, JOAN HENTHORN, MILICA BROZOVIĆ

Zinc and copper concentrations in leucocytes and erythrocytes in healthy adults and the effect of oral contraceptives LESLEY J HINKS, BARBARA E CLAYTON, RS LLOYD

Limitations of protein-coated charcoal in the separation of free from bound vitamin $B_{12}$ in serum ELIZABETH JACOB, KIT-TAI J WONG
Benefits of costing in the clinical laboratory PMG BROUGHTON, FP WOODFORD

Fine needle aspiration biopsy of the thyroid gland: $a$ 을 study of 304 cases KC SUEN, NF QUENVILLE

Immunological characterisation of plasminogen $\frac{\circ}{0}$ activators in the human vessel wall H LJUNGNER, $L \underset{\mathbb{D}}{ }$ HOLMBERG, A KJELDGAARD, IM NILSSON, B ÅSTEDT

Factor VIII as a marker of endothelial cells $\stackrel{0}{\text { în }}$ follicular carcinoma of the thyroid HR HARACH, JASANI, ED WILLIAMS

A quantitative study of the size of benign and malignant lymphoid follicles J CROCKER, EL JONES, RC CURRAN

Hepatocellular carcinoma complicating chronic $\stackrel{7}{\exists}$ granulomatous hepatitis WM MELIA, H CALVEY, B PORTMANN, R WILLIAMS

Necrotising granulomata in prostatic resection specimens-a sequel to previous operation G LEE, N SHEPHERD

Intramucosal carcinoma of the gastric antrum complicating Menetrier's disease GM WOOD, 오 CHRISTINE BATES, RC BROWN, MS LOSOWSKY

Recurrent insulinoma syndrome with metastatic glucagonoma PJS DUNN, MC SHEPPARD, DA HEATH,, G SLANEY

Technical method

An electron microscopy method for studying full cross-sections of the human renal glomerulus $\mathrm{SR}_{\overparen{D}}^{\circ}$ APARICIO, C WAKEFIELD

\section{Letters to the Editor}

\section{Notices}

